\title{
The provincial policies of Teti, Pepy I and Merenre in Upper Egypt
}

Sameh Shafik*

Higher Institute for Tourism and Hotels, Luxor (EGOTH), Egypt

\section{ARTICLE INFO}

Keywords:

Old Kingdom,

Upper Egypt,

Administration,

Reforms,

Decentralisation

\begin{abstract}
Relations between capital and provinces were particularly important for the successful administration of Old Kingdom Egypt. The royal court and the central bureaucracy depended on the provinces for economic provision and military protection. The present paper examines this relationship by a study of evidence from Old Kingdom tombs in a range of Upper Egyptian provinces as well as those in the capital cemeteries. The data suggests that with declining resources the central government was wavering between the need to decentralise the provincial administration by appointing governors to reside permanently in each province, and the risk of these ambitious, energetic officials taking root in their respective provinces, establishing power bases, and becoming impossible to remove as the generations progressed. In trying to solve this problem the central administration changed the provincial administrative system several times during the reigns of Teti, Pepy I and Merenre.
\end{abstract}

(C)2020 Faculty of Tourism and Hotels, Fayoum University All rights reserved

\section{Introduction}

This paper investigates the provincial administration of Upper Egypt in the reigns of the first three kings of the Sixth Dynasty, Teti, Pepy I and Merenre. This excludes Weserkare, whose reign was too short to have made a significant mark on the administrative system. When Teti came to the throne there is no evidence of provincial governors who took up residence or built a tomb in the province to which they were appointed. Instead, these elite bureaucrats administered their province remotely from Memphis with occasional visitations down the Nile to their province. After Teti assumed the crown, he appears to have introduced a new administrative policy for the provinces of Upper Egypt. The crown and the
Memphite bureaucracy were facing problems. Teti was unpopular as he was not the direct heir to the throne and was struggling for control against the powerful priesthood of $\mathrm{Re}$, many of whom belonged to the elite bureaucracy. Furthermore, already by the Fifth Dynasty it is likely that water levels had begun to decline making it increasingly difficult for the crown to support the administration and the bureaucracy. At the same period of time, it is likely that these elite officials were also finding their estates less productive. All this added to the unpopularity of Teti as ruler. Consequently, it is likely that Teti turned to the productive provinces of Upper Egypt to provide him with increased income to maintain the administration, support the elite bureaucracy and make sure that the produce of

\footnotetext{
${ }^{*}$ Contant Sameh Shafik at: samehshafik20@yahoo.com
} 
the provinces did not disappear in the hands of local people.

These problems, associated with income shortage, appear to have continued into the reigns of Teti's successors. Apart from a few years when Teti's son, Pepy I and his supporters, struggled to overcome Weserkare, the contender for the throne, Pepy I enjoyed a reign of considerable length. He was succeeded by Merenre whose reign was much shorter and who in turn was followed by the longlived Pepy II, whose years on the throne are beyond the purview of this investigation. While previous studies have dealt with aspects of these reigns (Helck, 1954; Baer, 1960; Kanawati, 1980; Kanawati and McFarlane, 1992; Moreno Garcia, 1997; Kanawati and Swinton, 2018; Martinet, 2019), the aim of the present paper is to examine the extent and significance of the changes to provincial policy introduced by the first three kings of the Sixth Dynasty. The available data from each Upper Egyptian province is examined separately, from south to north. Finally, general conclusions and hypotheses are considered.

\section{Literature Review}

\subsection{Province No. $2,^{2}$ Edfu}

$J z j$ 'Isi', whose fragmentary inscriptions indicate that he was appointed as provincial governor by Teti, is the first known provincial governor ( $h r j-t p$ $3 n s p 3 t$ ) of Edfu (Alliot, 1935, 22-28; Strudwick, 2005, No. 246). Like Hemre/ Isi I and Henqu II of Deir el-Gebrawi (see below), his titles were $j r j-p^{\top} t$ $h r j-t p$ ' $3 n s p 3 t$ 'hereditary prince, great overlord of the province' and $t 3 j t j z 3 b \underline{t} 3 t j$ 'supreme judge and vizier'. Like Henqu I (Davies, 1902B, pl. 38; Kanawati, 2005, pl. 37), Isi was also described as 'honoured before Ptah-Sokar', probably hinting at his Memphite origin. Isi must have continued in office for some time under Pepy I as one of his sons was named Ppjj-snb 'Pepyseneb' and is designated as ' $w$ ' $b$-priest, ka-servant' (Alliot, 1935, 26). $M r j j r{ }^{\top}-n f r / K 3 r$ 'Meryrenofer/ Qar', Isi's probable son, left a biography saying, 'I was a youth who tied the fillet in the time of Teti, and was brought by Pepy (I) to be $k m 3 t$ among the children of the overlords. I was appointed as sole companion and overseer of the palace guards ${ }^{3}$ under Pepy [I]. Then the majesty of Merenre had me to go south to Nome 2 , as sole companion, and overlord of the province'

\footnotetext{
${ }^{2}$ For the division of Upper Egypt into provinces and their limits and numbering, see Helck, 1974.
}

(Sethe, 1933, 253:18-254:4; El-Khadragy, 2002, 206ff.; Strudwick, 2005, No. 247). The exact meaning of $k m 3 t$ is not entirely clear. It could mean 'to create' or 'to form' (Hannig, 2003, 1334-34; Faulkner, 1962, 278; Kanawati and McFarlane, 1992, 47; Kanawati, 2011B, 217; Kanawati and Swinton, 2018, 100), but it has also been understood as 'to educate' (Strudwick, 2005, No. 247). However, if the purpose of bringing the children (perhaps the sons of the overlords to judge by the male determinative for $m s w$ in the text) to the capital was for education or even for education and training, this should have been for a limited time, no matter its length. But Meryrenofer/ Qar did not go back to Edfu following his so-called education/training and remained at Memphis for the rest of Pepy I's reign, and this, as will be demonstrated, applied to many of his peers. It may be argued that Meryrenofer/ Qar stayed there until the time came when he had to replace his father, Isi. However, Isi's inscriptions clearly indicate that he was first employed under Djedkare/ Isesi, was promoted by Wenis, was sent to Edfu by Teti (Alliot, 1935, 26; Strudwick, 2005, No. 247), and most probably continued his service under Pepy I; but did it last to the end of Pepy I's rather long reign? While this is not impossible, it seems unlikely. The fact that Meryrenofer/ Qar was allocated a site in the crowded cemetery of Teti and almost completed the building of his tomb there (Kanawati, 2011B, 217-231) may suggest that his return to Edfu was not planned or expected. It is also important to emphasise that he was sent back by Merenre, not by Pepy I. The verbs Meryrenofer/ Qar used to describe his coming to the capital and return to Edfu may also be significant, for he did not say, 'I came to the capital', but, 'I was jnj.tw.j 'brought' by Pepy I'. He also did not say, 'I was $r d j . t w . j$ 'appointed' to the office of ... by Merenre', but, 'I was hntj.tw.j 'sent south' by Merenre as ... .'Meryrenofer/ Qar seems to emphasise the fact that he was 'brought' to Memphis by Pepy I but it was Merenre who 'sent' him back to Edfu.I

\subsection{Province No. 4, Thebes}

Three tombs of nomarchs are known from Thebes. Saleh, who published the site, reasonably placed the tomb of Wnjs-' $n h$ 'Wenisankh' as the earliest, with a suggested date at the end of the Fifth Dynasty or the beginning of the Sixth (Saleh, 1977,

\footnotetext{
${ }^{3}$ For the translation of the title jmj-r hntjw-š pr-?3 see Kanawati, 2003, 14-24.
} 
17). Yet as a holder of the title 'great overlord of the province', Wenisankh is unlikely to have been earlier than the reign of Teti when this office was probably introduced. After his earlier rejection of this date (Kanawati, 1980, 132-142), Kanawati has reconsidered his dating, analysing the architectural, artistic, and inscriptional evidence in the tomb, and placing Wenisankh in the period of late Teti to early Pepy I (Kanawati and McFarlane, 1992, 7174). No other tombs are known from the reign of Pepy I, and the two other tombs on the site, those of Hntj 'Khenti' and Jhjj 'Ihy', are dated by both Kanawati and Harpur to the period of Merenre to middle Pepy II (Kanawati and McFarlane, 1992, 114-115, 297; Harpur, 1987, 281(681, 683). Martinet's dating of all three Theban nomarchs to the end of the Sixth Dynasty Martinet, 2019, 775777), seems unlikely. On the other hand, Kanawati's argument that Khenti was Ihy's father is not convincing. Saleh's suggestion that Ihy was Khenti's father is more plausible and is supported by both Harpur and Martinet (Saleh, 1977, 18-19). Although no solid conclusion about the exact chronology of the Theban nomarchs can be reached due to the scarcity of evidence, it appears that there is a gap between Wenisankh and Ihy, when no nomarch is attested at Thebes. The most likely date for this gap is the second half of Pepy I's reign, with Ihy presumably appointed by Merenre. Bearing in mind the fragmentary condition of the scenes and inscriptions in these tombs, it might be significant that the only person in the three nomarchic tombs who is described as 'honoured before Ptah-Sokar' is Jmjj 'Imy', the wife of Ihy (Saleh, 1977, pl. 17). Could that refer to a period the husband and wife spent at Memphis?

\subsection{Province No. 6, Dendera}

Two slabs and one tomb bearing the name of $M n j$ 'Meni' have been studied by Fischer. The first, an alabaster offering slab of 'Meni' with the beautiful name of $M n$ - $n h$-Ppjj 'Menankhpepy' was found at Saqqara. It belonged to a titled smr w'tj hrj-ḩbt jmj$r$ hmw-ntr jmj-r šnwtj 'sole companion, lector priest, overseer of priests, overseer of the two granaries. Both Meni and his wife were 'honoured before Hathor Mistress of Dendera' (Fischer, 1968, fig. 6). This connection with a local deity is found with other provincial officials buried in the capital and no doubt of similar time period. (See below).

\footnotetext{
${ }^{4}$ Fischer thinks that the owner of the stela might have been buried in his own nome (Fischer, 1962, 10).
}

A second offering slab found at Dendera belonged to a $s m r w^{`} t j$ hrj-tp $3 n s p 3 t M n j$ 'sole companion, great overlord of the province, Meni' (Fischer, 1968, fig. 19). The Dendera tomb belonged to a Menankhpepy, whose beautiful name was, Meni' (Petrie, 1900, pls. 1-4). He held the titles of h3tj-e hk 3 hwt smr $w^{\top} t j$ 'count, estate manager, sole companion.

Fischer thought that the owners of these objects possibly belonged to the same family, but that 'there is no reason to identify the nomarch with the owner of the Saqqara offering slab, and the apparent difference in date makes it unlikely that the latter is the same as the second Mni' (Fischer, 1968, 28, 85ff., 108, 170ff.). Fischer wrote that 'the precise date of Meni is difficult to establish with any degree of accuracy', yet without any convincing reason he tried to place the owner of the Dendera tomb in the Ninth Dynasty or later. The owner of this tomb had proudly recorded his titles as $h k 3 h w t$ 'estate manager' of the pyramids of both Pepy I and Merenre (Petrie, 1900, pl. 3), and this, together with his name of Menankhpepy, make a date in the Heracleopolitan Period highly unlikely. Menankhpepy/ Meni of Saqqara emphasised his Denderite connection: his title of 'overseer of priests' was typically held by nomarchs in different provinces. The discovery of his offering slab at Saqqara indicates that he had a tomb and expected to be buried there. In similar cases where an official built a tomb in the capital before he was sent to a province, certain decorated parts of the tomb in the capital were reused in his provincial tomb, although occasionally other parts were abandoned, or perhaps deliberately left behind (see provinces 2 and 9). Menankhpepy/ Meni's tomb at Dendera was probably constructed somewhat later, hence the titles in the pyramids of both Pepy I and Merenre. The evidence therefore suggests that after Menankhpepy/ Meni built a tomb at Saqqara, he constructed another at Dendera, with the probable date for it in the reign of Merenre.

\subsection{Province No. 7, Hamra Dom}

A stela (Berlin 7765) belonging to a governor of Nome No. 7 was found at Abydos. The governor was named $\underline{D} 3 t j$ 'Djati' but no tomb is known for him from the province and perhaps he was not buried there. ${ }^{4}$ Djati is described on the stela as

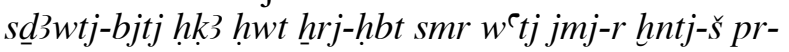




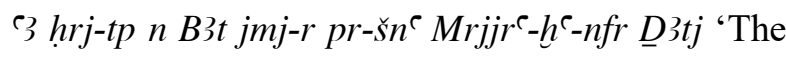
treaturer of the king of Lower Egypt, the estate manager, the lector priest, the sole companion, the overseer of the palace guard, the overlord of the Bat Nome, the overseer of the department of stores of the pyramid Meryre shines and is beautiful, Djati' (Fischer, 1962, 9-10, 16-17, fig. 4, pl.3). Both Baer and Fischer agreed on a date at the end of Pepy II's reign for Djati (Baer, 1960, 156, 242:590A; Fischer, 1962, 10), and Fischer considered that the confusion in the name of Pepy I's pyramid with that of Merenre ( $h{ }^{c}-n f r$ instead of $\left.m n-n f r\right)$ was indicative of a later date when the scribes were likely to make such an error. Yet this error is more likely to have occurred early in Merenre's reign, when his pyramid project was initiated, ${ }^{5}$ or during the highly controversial coregency of Pepy I and his son Merenre, if this coregency did exist (Kanawati and McFarlane, 1992, 92-93; Gourdon, 2016, 83-89). There is no reason for dating this stela later than the reign of Merenre, perhaps at the beginning of the reign. A comparison with Meryrenofer/ Qar of Edfu may be useful. Like Qar, Djati claimed only the modest rank of 'sole companion' and listed the office of 'overseer of the palace guards', which almost certainly could have been held only at Memphis. If Djati was appointed as nomarch of province No. 7 by Merenre, then his service in the capital was presumably during Pepy I's reign. Like Qar, Djati was also appointed to the position of hrj-tp 'overlord' and not hrj-tp 33 'great overlord' of the province (Sethe, 1933, 254:4). Whether these were variants of the same title, or a somewhat reduced status of the office, the writing was almost certainly deliberate and not an error. It is curious why Djati was buried at Abydos and not in his own province. The reason may be in the closeness of nomes 7 and 8 and the fact that Abydos became almost the capital of Upper Egypt, particularly with the royal descendants of $N b t$ 'Nebet' buried there (see below). Djati may have been the first governor to administer Nome No. 7 and was probably succeeded by two others buried in the province itself, who are referred to as $h r j-t p$ '3 'great overlord'. These were $\underline{T} 3 w t j j$ 'Tjauty' and $J d w / S n n j$ 'Idu/ Seneni', who held priesthoods in the pyramids of Pepy I, Merenre and Pepy II, and who are dated to the reign of Pepy II (SäveSöderbergh, 1994, passim). The fact that Idu/ Seneni appears in his father's tomb described as

\footnotetext{
${ }^{5}$ It is interesting that in another case, also from Abydos,
} (CG 1619) the scribe made the error in reverse, writing jmj-r hntj-s pr-e3 'overseer of the palace guards'(Säve-Söderbergh, 1994, pl. 22), and prominently lists the same title in his own tomb (Säve-Söderbergh, 1994, pls. 7-8), may refer back to the period when the administration under Pepy I was based at Memphis and when both Idu/ Seneni and his father were presumably based at the capital.

\subsection{Province No. 8, Abydos:}

Pepy I married the two daughters of Nebet and $H w j$ 'Khui', both named 'nh-n.s-Ppjj 'Ankhnespepy', and appointed his mother-in-law as vizier and his father-in-law as overseer of the Pyramid City. Contrary to Fischer who thought that Nebet was a commoner and her vizierate honorific (Fischer, 1976, 74-75; Fischer, 2000, 36-38; Gourdon, 2016, 133), Kanawati argued that she was of royal background, presumably as a descendant of Wenis, and as such Pepy I did not marry commoners, but instead was strengthening the ties his father began with the Wenis' family. He also suggests that Nebet was an actual vizier and not an honorific one (Kanawati, 2010A, 115-125). By appointing his inlaws to Abydos, Pepy I was presumably creating a major administrative centre in the middle of Upper Egypt, and the office remained in their hands for some time. Nebet was probably succeeded in the vizierate by her possible stepson, Jww 'Iuu' (Kanawati, 2009A, 43), whose tomb at Abydos has reasonably been dated to the latter part of Pepy I's reign or the beginning of that of Merenre (Brovarski, E. (1994), 24-33; Kanawati, 1980, 3233).

The biography of the well-known official $W n j$ 'Weni' recounts his long career as a Residence official under Teti and Pepy I (Sethe, 1933, 98-105; Strudwick, 2005, No. 256). We now know that he was the son of Iuu (Richards, 2002, 90, 94, fig. 16), yet he remained in the capital while his family was at Abydos. Despite his background, Weni held the rather modest titles of $s m r w^{\top} t j j m j-r$ hntj-š $p r-{ }^{-3}$ 'sole companion and overseer of the palace guards', even though he had enormous responsibilities, mainly in leading the Egyptian army a number of times under Pepy I (Sethe, 1933, 101-105; Strudwick, 2005, No. 256). He became tutor and sandal bearer, presumably in his old age, either at the end of Pepy I's reign or the beginning of that of Merenre. It was the latter king who at long last promoted Weni to the position of jmj-r

the name of Merenre's pyramid as Mrnr'-mn-nfr, then correcting $m n$ to $h^{\complement}$ (Borchardt, 1964, 90, pl. 83). 
$\breve{S} m^{`} w$ 'overseer of Upper Egypt' and the rank of h3tj- ' count' and presumably sent him to Abydos (Sethe, 1933, 105-106; Strudwick, 2005, No. 256). This probably was not meant to succeed his father in the vizierate, for his biography only mentions his appointment as overseer of Upper Egypt by Merenre. It seems likely that he was sent to Abydos as a reward for his services and perhaps to join his family. It was possibly later, either at the end of Merenre's reign or early under Pepy II, most probably after his biography and main false door were completed, that his father died and he followed him in the vizierate. A new false door was constructed and set into the exterior north wall of the mastaba commemorating this promotion and the adoption of a new 'beautiful name' Nfr-nhtMrjjre 'Nofernakhtmeryre' (Richards, 2002, 90, fig. 15).

Despite the fact that Weni's family was at Abydos during the reign of Pepy I, Weni remained at Memphis for most of his career. The discovery at Saqqara of some decorated blocks, now in the Egyptian Museum, Cairo, including two mini obelisks (CG 1309, CG 1310) and a relief fragment (CG 1670) (Borchardt, 1937, 6, pl. 2; Borchardt, 1964, 127, pl. 88; Richards, 2002, 79-81), suggests that Weni built a tomb there. In fact, the wording in Weni's autobiography of the cutting and delivery of his sarcophagus also suggests that it was delivered at Saqqara, with the boat which transported it $\underline{d} 3 j$ 'crossing' to Tura and $j n j$ 'returned' to Saqqara rather than sailing upstream (Sethe, 1933, 99:12-14; Kanawati, 1980, 53-54). In addition, the recent discovery by the French expedition at Saqqara of parts of a new version of Weni's biography leaves little doubt that he built a tomb there (Collombert, 2015, 145-157). The indication is that Weni planned to be buried in the capital far from his family at Abydos, until this was reversed by Merenre.

\subsection{Province No. 8, Naga el-Deir:}

Abydos became the seat of a vizier, presumably representing the central government in the South or a division of the South. ${ }^{6}$ Naga el-Deir, in Province No. 8, was the cemetery of the administrators of nome 8 , with many officials buried there, including two governors of the province, Tmrrjj 'Tjemerery' (tomb No. 248) (Peck, 1958, 40ff.) and H3gj 'Hagi' (tomb No. 89) (Fischer, 1954, 33 n. 64). These have

\footnotetext{
${ }^{6}$ Lashien suggests a division of Upper Egypt into two
} administrative sections, with a vizier residing in each. been dated to the very end of the Old Kingdom or later (Fischer, 1968 75, 130 n. 573; Peck, 1958, 127; Brovarski, 1982, 307-308; Martinet, 2019, 840). This dating of the two nomarchs has been discussed by many scholars, particularly that of Tjemerery, on whom more information is available. The architectural, artistic and inscriptional evidence from the tomb was compared with what was found in the neighbouring province of Akhmim, particularly in the tomb of the nomarch Nhwt-dšr 'Nehwet-desher' (tomb G95) (Kanawati, 1988, 7-13, pls. 1-2, 6-8, figs. 14). Kanawati and McFarlane suggested a date for Tjemerery and Hagi earlier in the Sixth Dynasty, although the order in which the two nomarchs held office is uncertain (Kanawati and McFarlane, 1992, 55-61). The most likely dates for the two nomarchs are the reigns of Teti and Pepy I.

Two great overlords of Nome No. 8, Ggj 'Gegi' (Borchardt, 1937, 142-143 (CG 1455); Borchardt, 1911, 60-63, pl. 17 (CG 70-75), and $H w-b 3 w$ 'Kheubau' (Jéquier, 1928, 27-28, figs. 34-35; Jéquier, 1929), 32, 129), whose dates are equally controversial were buried in the capital (Kanawati and McFarlane, 1992, 84-86). Because the governorship of Nome No. 8 was continuously held by the well dated nomarchs buried at Deir elGebrawi from the reign of Merenre to the end of that of Pepy II, Fischer wondered whether Gegi should be dated before or after the Deir el-Gebrawi nomarchs. He finally opted for the later date and placed both Gegi and Kheubau after the family of $J b j$ 'Ibi', $\underline{D}^{\top} w / \breve{S}^{\prime} 3 j$ 'Djau/Shemai' and $\underline{D}^{\Upsilon} w$ 'Djau' (Fischer, 1954, 33). It should be borne in mind that Gegi held the title of shd hmw-ntr of Merenre's pyramid and that his statues have been compared to those of Nhbw 'Nekhbu' (Smith, 1946, 88), who is securely dated to the reign of Pepy I. The objects from his tomb were discovered at Saqqara, but the location of the tomb is unknown. This does not appear to be dissimilar to other provincial officials who built tombs at Saqqara. $H w-b 3 w$ 'Kheubau' on the other hand was buried near the pyramid of Wedjebten in the cemetery of Pepy II. The type of his stela known as a stele-maison is typical of this reign, during which Kheubau presumably built his tomb.

Unlike other sons of nomarchs who were brought to the capital by Pepy I and sent back to their provinces by Merenre, Gegi and Kheubau

Thus, during Pepy I's reign viziers existed at Abydos and Deir el-Gebrawi (Lashien, 2017, 104-117). 
remained at Memphis and were buried at Saqqara. Gourdon is presumably correct in dating Gegi to the same period as Ibi of Deir el-Gebrawi, that is, Merenre to early Pepy II, and in suggesting that unlike Ibi, Gegi held the nomarchic title in a 'theoretical'/ honorific manner'. However, Gourdon's suggestion that Ibi was described as 'the real great overlord of Nome 8', a title not held by any of his descendants (Gourdon, 2016, 137-138), is not correct. Ibi in fact added $m 3^{\circ}$ after a number of other titles such as jmj-r $\breve{S} m^{\top} w, h 3 t j-{ }^{-}, h k 3 h w t$, htmtj bjtj, smr $w^{\top} t j$, but not after his nomarchic titles (Davies, 1902A, pls. 7-8, 13, 18-19; Kanawati, 2007, pls. 50, 54, 58), while his descendants, Djau/Shemai and Djau, added $m 3^{c}$ after many titles including those of hrj-tp 33 'great overlord' of both Nomes 8 and 12 (Davies, 1902B, pls. 3, 6, 9, 12-13). The significance of $m 3^{\mathrm{C}}$ after a title has been discussed by many scholars, but whether it indicated a real as against honorific/ theoretical holding of the office remains elusive. However, $m 3^{r}$ was used in many other contexts which could mean 'true', or even 'as it should be', as for example when Djau described himself in his joint tomb with his father Djau/ Shemai as z3.f smsw mrjj.f $n$ ht.f me 'his true eldest son, his beloved, of his body' (Davies, 1902B, pl. 10; Kanawati, 2013, pl. 62). Perhaps Djau/ Shemai had more than one eldest son by different wives (Kanawati, 1976, 235-251), although this is not recorded in his joint tomb with Djau, which was built by the latter.

The most likely reason why Gegi and Kheubau were not sent back to Nome No. 8 was that Abydos became a major administrative center headed by royal relatives, Nebet and her descendants. As a result, the responsibility for the administration of Nome No. 8 itself was added to the duties of Ibi and his family in Nome No. 12, who may well have been the descendants of the same royal relatives of Abydos (Baud, 1999, 629-631). This highly unusual arrangement was perhaps an administrative necessity to avoid possible friction between two authorities residing in Nome No. 8, even if one was buried at Abydos and the other at

\footnotetext{
${ }^{7}$ For the date of Nehwet-desher see also Moreno Garcia, 2005, 109.

${ }^{8}$ Stela Florence 7584 (Kanawati, 1987, 50, pl. 10b, fig. 37a; Kanawati and McFarlane, 1992, 91ff.) belongs to a nomarch who writes his title hrj-tp $n$ Hnt-Mnw, but his name is damaged. Kanawati and McFarlane's
}

Naga el-Deir. Yet at the same time Gegi and Kheubau, the probable descendants of Hagi and Tjemerery, the earlier governors buried at Naga elDeir, were not deprived of their nomarchic title, even though they were buried in the capital.

\subsection{Province No. 9, El-Hawawish:}

The first two known governors to administer Akhmim were a father, Nhwt-dšr 'Nehwet-desher' (tomb No. G95) and his son, Špsj-pw-Mnw 'Shepsipumin'. Unlike their successors, these two nomarchs wrote their title as hrj-tp $3 n s p 3 t$ 'great overlord of the province' rather than hrj-tp '3 $n$ Hnt-Mnw 'great overlord of Akhmim'. The son's name is only known from his father's tomb, which he claimed in an inscription to have decorated (Kanawati, 1988, pl. 1, fig. 3). ${ }^{7}$ A large tomb G98, in the immediate vicinity of tomb G95, may have belonged to Nehwet-desher's father, as a fragment of a basin bearing the title 'overseer of priests' was found in his burial chamber, while the small tomb G97 may have belonged to Nehwet-desher's son, Shepsipumin (Kanawati, 1988, 14-19, figs. 1-2, 5). The identity of the owners of these two tombs is however uncertain, although the dates of Nehwetdesher and his son have been discussed by Kanawati, who placed them at the end of Teti's reign and at the beginning of Pepy I's reign (Kanawati and McFarlane, 1992, 49-54). A nomarch of Akhmim named Iri was buried at Saqqara, near the area where the later king Userkare/ Khendjer of the $13^{\text {th }}$ Dynasty built his pyramid. Iri held the title of 'great overlord of Akhmim' and the rank of 'sole companion' (Jéquier, 1933, 40-41, fig. 30). He has been dated by Kanawati to the reign of Pepy I ((Kanawati and McFarlane, 1992, 83-84, 86), but his relationship to the governing family buried at Akhmim is unclear, and the name Iri may have been a new name or 'beautiful name' acquired while at Memphis.

The following nomarch buried at El-Hawawish was $K 3 . j-h p / T t j$ 'Kaihep/ Tjeti' of tomb No. M8, ${ }^{8}$ who left a biography summarising his career under Pepy I and his final promotion and nomarchic appointment, probably under Merenre..$^{9}$ As clearly

suggestion that the name may be Shepsipumin, is highly conjectural, and the stela may well belong to Kaihep/ Tjeti of tomb M8, made for him before or during his tomb was decorated.

9 The date of his tomb was disputed by a number of scholars. Kanawati originally proposed a date under 
demonstrated by Moreno Garcia, Kaihep/ Tjeti's titles emphasise his career in the capital rather than in the province (Moreno Garcia, 2005, 110). Indeed, in his tomb at El-Hawawish Kaihep/ Tjeti recorded the titles of 'overseer of the royal harem', 'overseer of all pleasures', 'keeper of the headdress', all offices connected with the palace (Kanawati, 1982, 7-8, pl. 1-2, figs. 8-9, 11-13. Yet the most surprising title he recorded is $w r m 3 w$ 'greatest of seers', indicating that at one stage of his career he became the high priest of Re, which as far as we know was an office not held by any other provincial governor in the Old Kingdom. Perhaps in order to control the priesthood of this important deity, Teti put the office in the hands of his viziers and sons-in-law, Mrrw-k3.j 'Mereruka' (Firth and Gunn, 1926, 133, 135; Duell, 1938, pls. 201 B; Kanawati, et al. 2010C, pl. 63; Kanawati, et al. 2011A, pls. 98-99, 103-104, 107) and K3.j-gm$n . j$ 'Kagemni' (Firth and Gunn, 1926, 107; Harpur, 2006, 508, drawing 25). For at least a part of his reign, Pepy I followed a similar policy to that of his father when the office of 'greatest of seers' was held by Ibi, the eldest son of the vizier Hntj-k3.j 'Khentika' (James, 1953, pl. 16; Moursi, 1972, 31), presumably in the earlier part of Pepy I's reign. It is likely that Kaihep/ Tjeti succeeded Ibi in the same reign, and before he was sent to Akhmim by Merenre.

A recently discovered tomb in the north-west section of the Teti cemetery belonged to a man whose name has been chiselled out and replaced by that of $J n-k 3 . f / J n j$ 'Inkaf/ Ini'. The preserved inscriptions of the original owner show that he held the important offices of jmj-r k3t nbt nt nswt 'overseer of all works of the king' and jmj-r hmw $n t r$ Mnw $n J p w$ 'overseer of priests of Min of Akhmim', and is described as jm3hw hr Mnw nb.f 'the honoured one before Min his lord' as well as 'the honoured one before Ptah-Sokar' and 'the honoured one before the king' (Kanawati, 2004B, 51-60, figs. 1-2). Being honoured by Min and PtahSokar may well indicate both the owner's origin from Akhmim and residence at Memphis where he was almost certainly close to and honoured before the king. The title 'overseer of priests' (of Min) was typically held by the nomarchs and probably

Merenre or early Pepy II (Kanawati, 1982, 10-14), but Brovarski wrote that the date 'is uncertain, although it is possible that he antedates the beginning of the Heracleopoli tan Period' (Brovarski, 1985, 132-133, 137). Moursi also placed him in the First Intermediate allowed its holder a certain income from the temple resources (Weeks, 1983, 5-22). In agreement with Moreno Garcia (2005, 111-113), the most likely interpretation of the data from Saqqara and Akhmim is that the original owner of the Saqqara tomb was Kaihep/ Tjeti who was sent to Akhmim by Merenre. Before Kaihep/ Tjeti left Memphis, he was entrusted with many demanding responsibilities in the capital, including the high priesthood of $\mathrm{Re}$ and overseeing all the works of the king. Jrj 'Iri' held the office of 'great overlord of Akhmim', but as a resident in the capital, as did other nomarchs at the time. The responsibilities of the temple of the important deity Min could not have been managed effectively by Kaihep/ Tjeti while he was in the capital. Thus, although he held the title of overseer of priests, which presumably provided him with income, another holder of the title named Wbnw 'Webenu' may have been sent from Memphis to be the acting 'overseer of priests' on location. Webenu, who was dated to the reign of Pepy I (Kanawati, 1986, 41-44, fig. 18; Kanawati and Mcfarlane, 1992, 50, 54 n. 243, 88), is the only overseer of priests at Akhmim who was not also great overlord of the province (Moursi, 1972, 3637, and passim). A man with this name appears in a prominent position among the offering bearers in the tomb of the vizier Meryteti, son of Mereruka and Seshseshet, and accordingly the nephew of Pepy I (Kanawati and Abder-Raziq, 2004C, 4950).

If the above scenario is correct, it would indicate that Pepy I was willing to send an overseer of priests to Akhmim to take charge of the affairs of the temple of Min and that the chosen person, Webenu, was probably close to and trusted by the royal family. However, the king was not ready to send a great overlord of the province to reside far from the capital. Thus, both Kaihep/ Tjeti and Iri remained at Memphis. That this was the decision of the king rather than the nomarchs may be gleaned from Kaihep/ Tjeti's description of his last promotion as 'my wishes were fulfilled most abundantly by the Residence under the Majesty of Merenre' (Ziegler, 1990, 270-273). It is an important feature that the probable tomb of Kaihep/ Tjeti in the Teti cemetery at Saqqara is close to

Period (Moursi, 1972, 36-37). Following the study of the decorated blocks originating from the tomb, Kaihep/ Tjeti is now securely dated to Merenre's reign. See McFarlane, 1987, 63-73; Ziegler, 1990, 270-273; Kanawati, 1988, 62, fig. 35. 
others whose owners bear names formed with that of the god Min and may have originated from Akhmim. More significant is the fact that the tomb is in the immediate vicinity of that built by Meryrenofer/ Qar of Edfu during his stay at Memphis under Pepy I (Kanawati, 2011B, 217231). After Kaihep/ Tjeti's return to Akhmim, the family continued to govern the province until the end of the Old Kingdom, with the immediate successors, K3.j-hp/ Ttj-jkr 'Kaihep/ Tjeti-iqer', Špsj-pw-Mnw/ $\underline{H} n j$ 'Shepsipumin/ Kheni' occupying the post under Pepy II. ${ }^{10}$

\subsection{Province No. 12, Deir el-Gebrawi}

The relative dating of the Old Kingdom cemeteries of the Twelfth Upper Egyptian province (Deir elGebrawi) and the individual dating of the tombs on the northern cliff have recently been studied by Kanawati. He showed that the topographical, architectural, artistic and inscriptional evidence consistently suggests that the northern cliff holds the earlier tombs, with the most likely dates for the four nomarchs as follows: Hnkw 'Henqu I': reign of Teti to early Pepy I; $H m-R{ }^{\top} / J z j$ 'Hemre/ Isi I': early to middle Pepy I; Henqu II: middle to late Pepy I and Hemre/ Isi II: late Pepy I (Kanawati, 2005, 11-20). ${ }^{11}$ Tomb No. N46 on the northern cliff, which belongs to Hemre/ Isi II, proved to be most astonishing in every respect. A doorway $(60 \mathrm{~m}$ wide $\mathrm{x} 1.07 \mathrm{~m}$ high) leads to a roughly finished rock cut chapel measuring $1.80 \mathrm{~m} \mathrm{E-W}$ on the south wall and $1.57 \mathrm{~m}$ on the north wall $\times 1.36 \mathrm{~m} \mathrm{~N}-\mathrm{S} \times 1.07 \mathrm{~m}$ high. The total area of the chapel is therefore 2.28 square metres and the height is $1.07 \mathrm{~m}$. While the north wall was plastered and poorly painted, the remaining walls have never been smoothed or plastered. The decoration is restricted to an irregular and hastily painted false door, and a scene showing four small figures of the tomb owner, his wife and two sons (Kanawati, 2005, 81, pls. 32, 59). The chapel floor is mostly occupied by the mouth of a single shaft, the depth of which is merely $1.16 \mathrm{~m}$, leading to a roughly cut burial chamber $1.98 \mathrm{~m} \times .65 \mathrm{~m}$, presumably just large enough to house a wooden coffin (Davies, 1902B,

\footnotetext{
${ }^{10}$ The dating of the two nomarchs has been discussed by a number of scholars, with varying conclusions. While Gomaà (1980), 84-86), and Brovarski (1985, 132-137) suggest a date during the First Intermediate Period, Kanawati and McFarlane (1992, 127-136), Strudwick, (1985, 254); Harpur, (1987, 21, 281), and Martinet
}

33, pl. 21; Kanawati, 2005, 80, pl. 58). This is a shockingly poor burial place considering that its owner held the highest administrative post of great overlord in this important province in middle Egypt, the most fertile and productive part of the country (Fisher, 1971, 496ff., fig. 19.6; Kanawati, 1980, 6-7; Lashien, 2017, maps 2-8). A comparison of the size of Hemre/ Isi II's tomb with those of his predecessors, who were buried on the same cliff, would demonstrate the enormity of the decline in size. Henqu I's chapel measures $8.00 \mathrm{~m} \times 4.30 \mathrm{~m}$, with a secondary room that probably served as a serdab, measuring 1.70m x 1.00m (Davies, 1902B, pl. 27; Kanawati, 2005, 24-25, pl. 35), thus an average area of 36.10 square meters. Hemre/ Isi I's tomb is $8.20 \mathrm{~m} \times 4.21 \mathrm{~m}$, with a secondary room, 4.22m x 2.08m (Davies, 1902B, pl. 16; Kanawati, $2005,41-42$, pl. 41), giving an average area of 43.29 square meters. Henqu II's chapel is $9.14 \mathrm{~m} \mathrm{x}$ $4.25 \mathrm{~m}$, with a secondary room $4.00 \mathrm{~m} \times 2.65 \mathrm{~m}$, thus an average area of 49.44 square meters (Davies, 1902B, pl. 22; Kanawati, 2005, 64-65, pl. 51).

These figures show that the area of the nomarchic tombs was gradually growing, reflecting perhaps their assumption of more responsibilities and wealth. This is not evident only in the size of their tombs, but equally so in their titles. While all four nomarchs buried on the northern cliff held the office of great overlord of UE 12, Henqu I added among his administrative duties the distinguished office of $j m j-r \breve{S} m^{\top} w$ 'overseer of Upper Egypt', although his highest rank was that of $h 3 t j-c$ 'count' (Davies, 1902B, 31; Kanawati, 2005, 21-22). On the other hand, Hemre/ Isi I and Henqu II occupied the top administrative office of $t 3 j t j \quad z 3 b \quad t 3 t j$ 'supreme judge and vizier' and rose to the rank of jrj-p`t 'hereditary prince' (Davies, 1902B, 19-20, 27; Kanawati, 2005, 37-38, 60). Yet there is no indication that such a rise in status and wealth was opposed to the king's will or that there was any challenge to his authority. In fact, Henqu I described himself as jmj jb $n n b . f$ 'favourite of his lord' (Davies, 1902B, pl. 28; Kanawati, 2005, pl. 37; Jones 2000, 44(231), and both Hemre/ Isi I and Henqu II refer to themselves as jm3hww hr $n b . f$ 'the

$(2019,879)$ propose a date in the second half of Pepy II's reign or immediately after.

${ }^{11}$ The recent attempt by Gourdon $(2016,136-138)$ and Martinet $(2019,918-923)$ to revert to the earlier opinion suggesting that the nomarchs buried on the northern cliff are later than those buried on the southern cliff, is unlikely. 
honoured one before his lord' ((Davies, 1902B, pls. 19, 23, 25; Kanawati, 2005, pls. 54, 56).

The last nomarch to be buried in the northern cliff, Hemre/ Isi II, lost the top administrative responsibility of vizier as well as the high ranks of 'hereditary prince' and 'count' and instead held the more modest rank of $s m r w^{\top} t j$ 'sole companion' (Davies, 1902B, 33; Kanawati, 2005, 79). He was also buried in an unusually impoverished tomb for a nomarch. The rise and fall of the fortunes of this governing family occurred within the reign of Pepy I. Following a break in the succession of the local administration of the province, presumably for a short period, a new governing family was appointed and moved its burial ground to a new site, the southern cliff. The first ruler of this family was $J b j$ 'Ibi', who fortunately left a biography clearly stating that he was appointed to this office by Merenre (Davies, 1902A, pl. 23; Kanawati, $2007,54, \mathrm{pl}$. 54). If the apparently deliberate action by Pepy I, in the second half of his reign, to curtail or to the responsibilities and wealth of Hemre/ Isi II of Nome No. 12 was restricted to this nomarch, it would have reflected a punishment for a personal misconduct of some sort, but as it applied to many or to all known nomarchs of different provinces, it seems to have been a deliberate policy by Pepy I.

\subsection{Province No. 14, Quseir el-Amarna and Meir:}

Like the governors of the Twelfth Nome of Upper Egypt, those of the neighbouring Fourteenth Nome were buried at two sites, Quseir el-Amarna and Meir. The chronology of these governors has recently been studied by several scholars (Lashien, 2017, 7-88; El-Khouli and Kanawati, 1989, 11-26; Kanawati, 2010B, 207-220). ${ }^{12}$ We here summarise these findings. It is now thought that Quseir elAmarna was the first site to be used for the burial of the governors of El-Qusiya. Although he did not carry the title of great overlord, $H w-n-W h$ 'Khewenwekh' was in fact the first known governor of the province. ${ }^{13}$ Lashien has drawn attention to the fact that Ppjj-' $n h-w r$ 'Pepyankh the Elder', owner of the second tomb at Quseir el-

\footnotetext{
${ }^{12}$ Polet's reconstruction of the history of the rulers of El-Qusiya (2008, 81-94), is unlikely.

${ }^{13}$ This goes against placing him at the end of the Old Kingdom, after the reign of Pepy II. See for example Harpur, 1987, 280(642).

${ }^{14}$ His likely false door was recovered in the northern section of the Teti cemetery, close to the tomb of Meryrenofer/ Qar of nome 2 and the likely tomb of
}

Amarna, was probably the son of Khewenwekh, whose name was Hnnj 'Heneni'. According to Lashien, Heneni acquired the name Pepyankh during a period spent at the capital, where he probably married a royal woman and built a tomb before returning to govern the province (Lashien, 2017, 86-87). The tomb of Pepyankh the Elder at Quseir el-Amarna is unfinished, with unsmoothed walls and very limited decoration. While this may be explained by his death shortly after his arrival, the fact that no shaft was excavated in the tomb for his probably royal wife, Ž̌žrt 'Seshseshet', even though she prominently appears with him on his false door, is curious (El-Khouli and Kanawati, 1989, 27-32, pls. 24-28). A possible scenario may be that work on the Quseir el-Amarna tomb came to a halt when Pepyankh the Elder was brought to Memphis, and although he built a tomb at Saqqara, ${ }^{14}$ it was his wish to be buried near his father. His wife presumably remained at Memphis as did his eldest son, Sbk-htp/ Nj- ${ }^{-} n h-P p j j / ~ H p j$ 'Sobekhotep/ Niankhpepy/ Hepi', who was buried in the Wenis cemetery at Saqqara (Kanawati, 2004A, 49-61, figs. 1-3). The most likely dates for Khewenwekh and Pepyankh the Elder are the end of Teti's reign and the first half of that of Pepy I.

Ppjj-'nh-hrj-jb 'Pepyankh the Middle' inaugurated the cemetery of Meir. He probably spent the earlier part of his career with his father at Memphis as many of his titles, such as $z \check{S}^{`} w n s w t$ $h f t-h r$ 'scribe of the royal records in the presence' may indicate. After a detailed study of the evidence from his tomb, Lashien concluded that both he and his wife claimed royal heritage by representing themselves seated on a block chair with the sign for $h w t$, a type of chair used by individuals with royal background (Lashien, 2017, 87). ${ }^{15}$ This may be due to the fact that he was the grandson of Seshseshet, wife of Pepyankh the Elder. However, in his biography Pepyankh the Middle wrote, 'never was I put under guard, never was I imprisoned. As for everything that was said about me in the presence of the srw, I came out from it with success, while (the charge) was thrown back upon the accusers,

Kaihep/ Tjeti of nome 9 (see Lashien, 2017, 284-286, figs. 5-6).

15 For some examples of this chair see (Kanawati, 2009B, 16); See also Queens Nebet, wife of Wenis (Munro, 1993, pls.12, 16, 27); Iput, wife of Teti (Firth and Gunn, 1926, pl. 55); and Neit and Iput, wives of Pepy II (Jéquier, 1933B, 24), and others. 
since I was cleared in the presence of the $s r w$, for they indeed spoke against me in slander' (Blackman, 1924, 25, pl. 4A; Kanawati, 2012, 3334, pl. 76a; Strudwick, 2005, No. 270). The tomb owner did not specify the nature of the accusations, but as they were considered before the srw, the highest level of officials, they may have been related to the person of the king and/or to the administration. We know that the reign of Pepy I was fraught with problems and court cases and that he surrounded himself by the sons of nomarchs (Kanawati, 1981, 203-217; Kanawati, 2003, 169182). Could the incident referred to by Pepyankh the Middle be one of these events?

Pepyankh the Middle's tomb has been dated by Baer to his period VIE (Pepy II, year 35- 55) (Baer, 1960, 289(133), and by Harpur to the period after the reign of Pepy II (Harpur, 1987, 280(650). In her recent study of El-Qusiya, Lashien has dated the tomb to late under Merenre or early under Pepy II. She has convincingly demonstrated that his tomb was decorated by K3.j-m-tnnt 'Kaiemtjenenet' who earlier decorated the tomb of $M h w$ 'Mehu' at Saqqara and who is represented in both tombs (lashien, 2017, 153-156). The tomb of Mehu is dated by Altenmüller to the reigns of Teti and Pepy I (Altenmüller, 1998, 82-83), by Strudwick too early to middle of Pepy I's reign (Strudwick, 1985, 101-102(69), and by Harpur to middle of Pepy I to Merenre (Harpur, 1987, 274(424). Baud however thinks that Harpur's addition of Merenre is unjustified (Baud, 1999, 471). The most likely date for the completion of Mehu's tomb is the reign of Pepy I, and for that of Pepyankh the Middle is the reign of Merenre or early under Pepy II. The following governors of El-Qusiya continued to be buried at Meir for the remainder of the Old Kingdom as well as into the Middle Kingdom, with no return to Quseir El-Amarna.

\subsection{Province No. 15, Sheikh Said}

Sheikh Said is a site that needs re-recording according to modern standards ${ }^{16}$ : until then any conclusions related to the site should remain tentative. Ttj- $n h / J j-m-h t p$ 'Tetiankh/ Imhotep' and $\mathrm{Mrw} / \mathrm{Bbj}$ 'Meru/ Bebi', the top administrators of this province early in the Sixth Dynasty, continued to hold the older type of titles, such as smr $w^{\top} t j$, hrj-tp nswt pr-`3, jmj-r njwwt m3wt 'sole companion, royal chamberlain of the palace, overseer of the new towns'. Tetiankh/ Imhotep was also $h k 3 h w t$ 'estate manager' of the estates of Teti, while Meru/ Bebi was $h k$ $h$ hwt 'estate manager' of the estates of both Teti and Pepy I, and he added for the first time the title of $j m j-r \breve{S} m^{`} w$ 'overseer of Upper Egypt' (Davies, 1901, 24, 31, pls. 17-21, 28 30).

The following governor was $W j w / J J w$ 'Wiu/ Iiu' (Davies, 1901, 27, pls. 21-24). His tomb (No. 19) is immediately next to that of Meru/ Bebi (No. 20), whose eldest son was called Wiu. The two tombs are also similar in their architectural design, and accordingly they probably belonged to a father and son. Wiu/ Iiu's titles show a complete change from the older type, for he continued to hold the title 'overseer of Upper Egypt', and added for the first time the office of 'great overlord of the Hare Nome' and the rank of 'count'. As the son of a provincial governor under Pepy I, Wiu/ Iiu was presumably expected, like other sons of nomarchs, to be brought to the capital. Although no inscription directly referring to his sojourn in the capital is available, this may be inferred from Wiu/ Iiu's description twice as 'the honoured one before Ptah-Sokar' (Davies, 1901, pls. 21, 23). His date has been studied by a number of scholars. Thus, according to Baer, he fits in his period VIC (Merenre to Pepy II, year 15) (Baer, 1960, 289(106). Harpur dates him to the period Merenre to early Pepy II (Harpur, 1987, 280(635), while according to Kanawati and McFarlane he belongs to the period from reign of Merenre to the beginning of that of Pepy II (Kanawati and McFarlane, 1992, 300). The most likely date is that of Merenre as he was presumably sent back to his province like all other nomarchs, and like them he was granted the title 'great overlord' of his province.

\section{Methodology}

There is currently mounting evidence of a decline in flood levels and in consequent resources during the latter part of the Old Kingdom. It is the aim of the present paper to examine the central government's responce to this situation, and to investigate whether the administrative reforms introduced into Upper Egypt by Teti were maintained or altered by each of his successors. The data from each province has to be collected, organised separately and correlated with that from the capital. It is essential to date the tombs according to the latest scholarly studies using all

\footnotetext{
16 The last record of the site is by Davies, 1901.
} 
the available criteria; then to place the structures and the evidence they contain into chronological order. The development in each province requires separate identification before the policy followed by each king becomes apparent. In reading the names of all the officials, we were guided by the work of Ranke, 1935.

\section{Conclusions}

From the above survey of data drawn mainly from the tombs located in the cemeteries of Upper Egypt the following conclusions and hypotheses may be drawn. It is very likely that Teti introduced the office of 'great overlord of the province'. Despite the fact that the data is by no means completely preserved, it appears that officials with this responsibility were sent to a number of selected provinces. On the assumption that the dating we accepted is correct, the following nomarchs (provincial governors) were appointed by Teti or early in the reign of Pepy I: Isi to Nome 2, Wenisankh to Nome 4, Tjemerery and Hagi to Nome 8, Nehwet-desher and Shepsipumin to Nome 9, Henqu I, Hemre/ Isi I: Henqu II: Hemre/ Isi II to Nome 12, Khewenwekh and Pepyankh the Elder to Nome 14, and Tetiankh/ Imhotep and Meru/ Bebi to Nome 15.

During the latter part of Pepy I's reign the children of the nomarchs, and occasionally the viziers, were brought to Memphis for 'education'. Under Pepy I none appears to have returned to his province to succeed his father. On the contrary, many of these sons of dignitaries built tombs at Saqqara. Those known to have done so are: Meryrenofer/ Qar of Nome 2, Meni/ Menankhpepy of Nome 6, Weni of Nome 8, Gegi and Kheubau also of Nome 8, Kaihep/ Tjeti of Nome 9, Heneni/ Pepyankh the Elder and Sobekhotep/ Niankhpepy/ Hepi of Nome 14. Of these 'sons' of dignitaries Meryrenofer/ Qar, Meni/ Menankhpepy, Weni, Kaihep/ Tjeti, Heneni/ Pepyankh were returned to their provinces by Merenre where they were buried. Sobekhotep/ Niankhpepy/ Hepi who presumably died before he was returned, was buried at Saqqara. Gegi and Kheubau of Nome 8 remained in the capital under Pepy II as the administration of Nome 8 was added to that of the nomarchs of Nome 12. Ihy of Nome 4 was probably also appointed by Merenre, but his relationship to Wenisankh is unknown, while Wiu/

\footnotetext{
${ }^{17}$ Gourdon has also observed that burials of nomarchs in their provinces have increased under Merenre (Gourdon, 133).
}

Iiu of Nome 15 succeeded his father Meru/ Bebi who also served under Merenre. Djati of Nome 7 was appointed by Merenre, but was buried at Abydos, perhaps for one of the following reasons: the lack of a cemetery at the time in Nome 7, the closeness of Abydos to Nome 7 and its consideration as a mini capital for the South, or the existence of a kind of kinship between Djati and the royal in-laws at Abydos. The following governors of Nome 7, Tjauty and Idu/ Seneni, were buried in their own province.

From the above data it is highly likely that Teti initiated a system where a certain amount of the crown's administrative power was transferred to the governors of a number of Upper Egyptian provinces. As a nomarch was not appointed to every province there may not have been sufficient time to send an official representing the king to all the provinces. It is also possible that some provinces were chosen for their capacity to supply the crown, while others such as Edfu were chosen for their geographical or defensive location. In the latter part of his reign Pepy I appears to have reversed his father's policy, bringing the sons, successors to the presiding nomarchs to Memphis and employing them in the central administration. This policy may have antagonised many of the higher officials as it was reversed again when Merenre came to the throne. ${ }^{17}$ The evidence suggests that the policies of the crown were not applied to all provinces at the same time, but were executed in each province as the need or opportunity presented itself.

\section{References}

Alliot, M. (1935). Rapport sur les fouilles de Tell Edfou 1933, Cairo.

Altenmüller, H. (1998). Die Wanddarstellungen im Grab des Mehu in Saqqara, Mainz.

Baer, K. (1960). Rank and Title in the Old Kingdom. The Structure of the Egyptian Administration in the Fifth and Sixth Dynasties, Chicago.

Baud, M. (1999). Famille royale et pouvoir sous l'Ancien Empire égyptien, 2 vols., Cairo.

Blackman, A.M. (1924). The Rock Tombs of Meir 4, London.

Borchardt, B. (1911). Statuen und Statuetten von Königen und Privatleuten 1, Cairo.

Borchardt, B. (1937). Denkmäler des Alten Reiches im Museum von Kairo 1, Berlin. 
Borchardt, B. (1964). Denkmäler des Alten Reiches im Museum von Kairo 2, Cairo.

Brovarski, E. (1982). Naga ed-Dêr. in: Lexikon der Ägyptologie 4, Helck, W. ed., Wiesbaden, 296-318.

Brovarski, E. (1985). Akhmim in the Old Kingdom and First Intermediate Period. in: Mélanges Gamal Eddin Mokhtar 1, P. Posener-Kriéger ed., Cairo, 117-153.

Brovarski, E. (1994). Abydos in the Old Kingdom and First Intermediate Period, Part II. in: For His Ka, Essays Offered in Memory of Klaus Baer, Silverman, D.P. ed., Chicago, 15-44.

Collombert, Ph. (2015). Une nouvelle version de l'autobiographie d'Ouni, in: Cinquante ans d'éternité: Jubilé de la Mission archéologique française de Saqqâra, Legros R. ed., Cairo, 145157.

Davies, N. de G. (1901). The Rock Tombs of Sheikh Saïd. London.

Davies, N. de G. (1902A). The Rock Tombs of Deir el Gebrâwi 1, London.

Davies, N. de G. (1902B). The Rock Tombs of Deir el Gebrâwi 2, London.

Duell, P. (1938). The Mastaba of Mereruka. 2 vols., Chicago.

El-Khadragy, M. (2002). The Edfu offering niche of Qar in the Cairo Museum. SAK 30, 203-228.

El-Khouli, A. and Kanawati, N. (1989). Quseir elMarna: The Tombs of Pepy-ankh and Khewenwekh, Sydney.

Faulkner, R.O. (1962). A Concise Dictionary of Middle Egyptian, Oxford.

Firth, C.M. and Gunn, B. (1926). Teti Pyramid Cemeteries, 2 vols., Cairo.

Fischer, H.G. (1954). Four provincial administrators at the Memphite cemeteries. JAOS 74, 26-34.

Fischer, H.G. (1962). "The cult and nome of the Goddess Bat", JARCE 1, 16-17, pl.3, fig. 4.

Fischer, H.G. (1968). Dedera in the Third Millennium B.C. Down to the Theban Domination of Upper Egypt, New York.

Fischer, H.G. (1976). Egyptian Studies I: Varia, New York.

Fischer, H.G. (2000). Egyptian Women of the Old Kingdom and of the Heracleopolitan Period, New York.

Fisher, W. B. (1971). The Middle East: A Physical, Social and Regional Geography, London.

Gomaà, F. (1980). Ägypten während der Ersten Zwischenzeit, Wiesbaden.

Gourdon, Y. (2016). Pepy Ier et la VIe dynastie, Paris.

Hannig, R. (2003). Ägyptisches Wörterbuch 1: Altes Reich und Erste Zwischenzeit, Mainz am Rhein.

Harpur, Y. (1987). Decoration in Egyptian Tombs of the Old Kingdom: Studies in Orientation and Scene Content, London.

Harpur, Y. and Scremin, P. (2006). The Chapel of Kagemni Scene Details, Oxford.
Helck, W. (1954). Untersuchungen zu den Beamtentiteln des ägyptischen Alten Reiches, Glückstadt.

Helck, W. (1974). Die altägyptischen Gaue, Wiesbaden. James, T.G.H. (1953). The Mastaba of Khentika Called Ikhekhi, London.

Jéquier, G. (1928). La pyramide d'Oudjebten, Cairo.

Jéquier, G. (1929). Tombeaux de particulier contemporains de Pepi II, Cairo.

Jéquier, G. (1933A). Deux pyramides du Moyen Empire, Cairo.

Jéquier, G. (1933B). Les pyramides des reines Neit et Apouit, Cairo.

Jones, D. (2000). An Index of Ancient Egyptian Titles, Epithets and Phrases of the Old Kingdom, Oxford.

Kanawati, N. (1976). "The mentioning of more than one eldest child in Old Kingdom inscriptions", Chron. d'Ég. 51, 235-251.

Kanawati, N. (1980). Governmental Reforms in Old Kingdom Egypt, Warminster.

Kanawati, N. (1981). Deux conspirations contre Pépy Ier, Chron. D'Ég. 56, 203-217.

Kanawati, N. (1982). The Rock Tombs of El-Hawawish: The Cemetery of Akhmim 3, Sydney.

Kanawati, N. (1986). The Rock Tombs of El-Hawawish: The Cemetery of Akhmim 6, Sydney.

Kanawati, N. (1987). The Rock Tombs of El-Hawawish: The Cemetery of Akhmim 7, Sydney.

Kanawati, N. (1988). The Rock Tombs of El-Hawawish: The Cemetery of Akhmim 8, Sydney.

Kanawati, N. and McFarlane, A. (1992). Akhmim in the Old Kingdom 1, Sydney.

Kanawati, N. (2003). Conspiracies in the Egyptian Palace: Unis to Pepy I, London.

Kanawati, N. (2004A). Niankhpepy/ Sebekhetep/ Hepi: Unusual tomb and unusual career. GM 201, 49-61.

Kanawati, N. (2004B). Interrelation of the capital and the provinces in the Sixth Dynasty. BACE 15, 5160.

Kanawati, N. and Abder-Raziq, M. (2004C). Mereruka and His Family I: The Tomb of Meryteti, Oxford.

Kanawati, N. (2005). Deir el-Gebrawi 1, Oxford.Kanawati, N. (2007). Deir el-Gebrawi 2, Oxford.

Kanawati, N. (2009A). Weni the Elder and his royal background. In: En Quête de la lumière: Mélanges in honorem Ashraf A. Sadek, Maravelia, A.A. ed., Oxford, 33-49.

Kanawati, N. (2009B), The Teti Cemetery at Saqqara 9, Oxford.

Kanawati, N. (2010A). The vizier Nebet and the royal women of the Sixth Dynasty. In: Thebes and Beyond: Studies in Honour of Kent R. Weeks, Hawass, Z. and Ikram, S. eds., Cairo, 115-125.

Kanawati, N. (2010B). Chronology of the Old Kingdom nobles of El-Qusiya revisited. In: Perspectives on Ancient Egypt: Studies in Honor of Edward 
Brovarski, Hawass, Z. Der Manuelian, P. and Hussein, R.B. eds., Cairo, 207-220.

Kanawati, N., Woods, A., Shafik, S. and Alexakis, E. (2010C). Mereruka and His Family III:1, Oxford.

Kanawati, N., Woods, A., Shafik, S. and Alexakis, E. (2011A). Mereruka and His Family III:2, Oxford.

Kanawati, N. (2011B). "The Memphite tomb of Qar of Edfu", in: Time, Signs and Pyramids: Studies in Honour of Miroslav Verner on the Occasion of His Seventieth Birthday, Callender, V.G., et al. (eds.), Prague, 217-231.

Kanawati, N. (2012). The Cemetery of Meir 1, Oxford.

Kanawati, N. (2013). Deir el-Gebrawi 3, Oxford.

Kanawati, N. and Swinton, J. (2018). Egypt in the Sixth Dynasty: Challenges and Responses, Wallasey.

Lashien, M. (2017). The Nobles of El-Qusiya in the Sixth Dynasty: A Historical Study, Wallasey.

Martinet, É. (2019). L'Administration provinciale sous l'Ancien Empire égyptien, Leiden.

McFarlane, A. (1987). The first nomarch at Akhmim. GM 100, 63-73.

Moreno Garcia, J.C. (1997). Études sur l'administration, le pouvoir et l'idéologie en Égypte, de l'Ancien au Moyen Empire, Liège.

Moreno Garcia, J. C. (2005). Deux familles de potentats provinciaux et les assises de leur pouvoir: Elkab et El-Hawawish sous la VIe Dynastie. Rev.d'Ég. 56, 95-128.

Moursi, M. (1972). Die Hohenpriester des Sonnengottes von der frühzeit Ägyptens bis zum Ende des Neuen Reiches, Berlin.
Munro, P. (1993). Das Unas-Friedhof Nord-west, Mainz.

Peck, C. (1958). Some Decorated Tombs of the First Intermediate Period at Naga ed-Dêr ( $\mathrm{PhD}$ thesis, Brown University).

Petrie, W.M.F. (1900). Dendereh 1898, London.

Polet, S. (2008). Généalogie et chronologie chez les nobles de Meir et de Koçeir à l'Ancien Empire. Studi di Egittologia 5, 81-94.

Ranke, H. (1935). Die Ägyptischen Personennamen, 3 vols., Glückstadt.

Richards, J. (2002). Text and context in Late Old Kingdom Egypt: The archaeology and historiography of Weni the Elder. JARCE 39, 75101.

Saleh, M. (1977). Three Old-Kingdom Tombs at Thebes, Mainz am Rhein.

Säve-Söderbergh, T. (1994). The Old Kingdom Cemetery at Hamra Dom (El-Qasr wa Es-Saiyad), Stockholm.

Sethe, K. (1933). Urkunden des Alten Reichs 1, Leipzig.

Smith, W.S. (1946). A History of Egyptian Sculpture and Painting in the Old Kingdom, Oxford.

Strudwick, N. (1985). The Administration of Egypt in the Old Kingdom, London.

Strudwick, N.C. (2005). Texts from the Pyramid Age, Atlanta.

Weeks, N. (1983). "Care" of officials in the Egyptian Old Kingdom. Chron. D’Ég. 58, 5-22.

Ziegler, C. (1990). Catalogue des stèles, peintures et reliefs égyptiens de l'Ancien Empire et de la Première Periode Intermédiaire, Paris 